\title{
SOCIAL DIFFERENCES IN HOUSEHOLD STRUCTURES IN THE 19TH CENTURY: MOSCOW AND ITS OUTSKIRTS*
}

\author{
ALEXANDRE AVDEEV, IRINA TROITSKAYA, GALINA ULIANOVA
}

\begin{abstract}
During the last few decades, ideas about household structures in the territories lying east of the Hajnal line have changed considerably. Not only has the line itself been transformed into a fairly wide 'transitional' zone and its location on the European map been changed, but the variety of family forms found behind the generalised characteristics of the "Eastern" territories has made scholars re-examine certain theoretical concepts and findings.
\end{abstract}

The new concepts are based on the growing number of micro-studies covering the territories of Central and Eastern Europe and provide very detailed information on family size and structures. For Russia, which has always been considered a model of the Eastern type of household organisation, new data have appeared as well, making it possible to re-examine the theories concerning Russian households.

However, scholars more often pay attention to geographic rather than social stratification of household types. The majority of studies are devoted to the social group of peasants, especially of peasant serfs, while household structures in other social groups are less explored.

In this article, we seek to fill this gap by providing a comparison of household structures in two social groups, namely of Moscow merchants and of serfs who lived near Moscow in the middle of the 19th century. The household structures in the two groups were entirely different: one in two merchant families was a nuclear one consisting of a couple with or without children, or a single parent with children, while in the peasant population multiple households, including several nuclearfamilies, predominated (60\% of the total number of households). The most likely explanation for this is the two groups' different obligations to the state.

Key words: Hajnal line, household classification, revisions, merchants, peasants.

\author{
"West is West, East is East, \\ and never the twain shall meet ..." \\ Rudyard Kipling, \\ "The Ballad of East and West" (1889)
}

Where is the border between East and West? We can assume that for Kipling, this conclusion, based on his life in Britain and the British colonies, was not in any doubt, but a resident of continental Europe would have a hard time giving a clear answer to the question. And yet, one possible answer is provided by the results of a project studying fertility in Europe (The European Fertility Project), better known in scientific circles as the Princeton Project.

\footnotetext{
Alexandre Avdeev, Institute of Demography, University Paris 1 «Panthéon Sorbonne», Paris. LOMONOSOV MOSCOW STATE UNIVERSITY, RUSSIA.

IrINA TroITSKAYA (itro@econ.msu.ru), LOMONOSOv MOSCOW STATE UNIVERSITY, RusSia. Galina Ulianova. InSTITUTE of Russian History, Russian ACADEMy Of SCIENCES, Russia.
}

* The original aRTiCle in Russian WAS PUblished in DEMOgRaPhic REVIEW, 2015, 2(2): 74-91.

URL: HTTPS://DEMREVIEW.HSE.RU/2015--2/167970569.HTML

THE STUDY WAS CONDUCTED WITH THE SUPPORT OF THE RUSSIAN FOUNDATION FOR THE HUMANITIES, PROJECT 15-O100362 «A DEMOGRAPHIC HISTORY OF THE MOSCOW MERCHANT CLASS ACCORDING TO THE LISTS OF THE 3RD-1OTH REVISIONS (1762-1858): MARRIAGE AND FAMILY, FERTILITY AND MORTALITY, SOCIAL AND SPATIAL MOBILITY». 
The project was initiated by A. Coale in the late 1950s, a time when the model of demographic transition - still relatively new and widely discussed - needed data to support it. Therefore, one of the main goals of the project was to study the characteristics of the demographic transition in certain European countries. An international team of then young demographers, today world-famous scientists (B. Anderson, J. Knodel, R. Lesthaeghe, M. Livi Bacci, E. Van de Walle, et al.), participated in the project and, using project data, described in detail how and when the demographic transition took place in Europe [Coale 1969; Coale, Anderson, Harm 1979; Coale, Watkins 1986; Knodel 1974; Lesthaeghe 1977; Livi Bacci 1971, 1977; Van de Walle 1974].

But in addition to answers to important questions about the patterns of the demographic transition and, above all, the drop in fertility in Europe, the project gave several interesting results of a more general nature, including those which led to the conclusion that temporal and geographic differences in nuptiality played a very important role in the reduction of fertility [Tilly 1986: 324] - a conclusion that confirmed the European marriage patterns, already well known by that time, of J. Hajnal and of his famous, albeit not exactly straight line connecting St. Petersburg and Trieste [Smith 1990: 172].

According to the Hajnal model, the decline in fertility to the west of this line was due not only to voluntary birth control after reaching the desired number of children in the family and to lengthening the intervals between births [Knodel 1974], but also to the postponement of marriage for quite a considerable period of time [Hajnal 1965] - a conclusion that seems obvious today but in the mid-1960s was an important scientific discovery and determined for many years to come a whole area of research in demography.

Once the Hajnal line had divided Europe into "East" and "West" by a purely demographic criterion, many could not resist the temptation to use it not only to separate, but also to contrast Eastern and Western Europe, for example, by the degree of democratisation, IQ parameters, level of corruption, civic consciousness, etc. ${ }^{1}$

In the early 1970s, P. Laslett, noticing differences in the types of family structures in Western and Eastern Europe, used the Hajnal line to divide Europe on this basis [Laslett 1972]. Note, however, that over time, as new data appear - especially for countries that do not belong to Northern or Western Europe - the border becomes more and more blurred and less obvious, and behind the differences in household types profound differences in family systems integrated into the wider socio-economic context can be seen [Todd 1983]. Nevertheless, it can be stated that, until the end of the 1980s, the Hajnal line represented a border to the west of which knowledge regarding the structure of households was more or less documented.

Recent decades have significantly changed our understanding of the types of households in the territories lying to the east of the Hajnal line. Not only has the line itself turned into a fairly extensive "transition" zone, and not only has its position on the map of Europe changed [Kaser 2001; Mitterauer 2003], but also the variety of types of marriage and family found behind the generalised characteristics of Eastern and Central European territories has led researchers to reconsider some of the theoretical concepts and results of earlier studies [Szołtysek 2007].

\footnotetext{
${ }^{1}$ See for example: https://hbdchick.wordpress.com/2014/03/10/big-summary-post-on-the-hajnal-line/. 
This expansion of the boundaries of the phenomenon under study was made possible by a growing number of micro-studies providing detailed information about the size and composition of households in Central and Eastern Europe. New data have appeared also for Russia, which has always been considered a classic example of an "Eastern" type of family formation and household organisation, and they too provide a basis for the revision of existing ideas about the Russian family. Studying the forms of Russian families and households based on individual data allows us to apply standard classifications of types of households to Russian sources and to obtain results that are comparable with European ones.

Existing studies more often take into account the geographical rather than the social stratification of types of households; researchers critical of the Hajnal model point to its excessively "demographic approach to the study of family history, ignoring the significant differences between classes" [Kaiser 1992: 39]. The object of the overwhelming majority of studies of Russian household types is the social group of peasants, a fact largely due to the quantitative predominance of this class in the population of the Russian Empire in the 19th century; it is precisely their demographic behaviour which determined rates of fertility, mortality and natural increase during this period. In addition, the formation and functioning of serf households explored in this article are fairly well documented. Official sources, such as revision or confession lists, are supplemented by orders from the landlord or his administrators, correspondence between them concerning affairs on their estates, inventories of local households, instructions of clerks concerning estate management, records of punishments and lists of passports issued.

Other social classes, relatively few and less susceptible to external control requiring documentation, have been studied in much less detail. We have tried to bridge this gap by presenting in this article a comparative analysis of the structures of households in two estates (suburban Moscow merchants and serfs) in the middle of the 19th century. The results of an analysis of household structures in the Vykhino votchina ${ }^{2}$ have already been presented in earlier works of the authors [Blum, Troitskaya, Avdeev 2000]; data on the size and structure of the households of Moscow merchants in the middle of the 19th century, estimated from a $10 \%$ sample and presented in a form comparable with the results of similar studies, are now published for the first time.

\section{SUBJECT OF THE STUDY AND DATA SOURCES}

The sample, on which our comparative study of class differences in the structures of households in the middle of the 19th century is based, includes about 3,000 persons: more than 1,500 representatives of the merchant class living in two large Moscow slobodi, ${ }^{3}$ and about 1,400 serfs

\footnotetext{
${ }^{2}$ A patrimonial estate.

${ }^{3}$ Sloboda (settlement): Until the 18th century this was a small, autonomous part of a city. In the 18th century, during the first revision, Moscow was divided into sections, which were called hundreds, fifties and slobodas; later, hundreds and fifties were renamed slobodas. For the merchants and petty-bourgeois of Moscow, this division remained until the end of the 19th century (at least until the publication of "Materials for the history of Moscow merchants"). Historically, a sloboda was a place of settlement of a corporative community, which had certain freedoms. Thus, in the Sadovnicheskaya sloboda lived horticulturists, and in the Kadashevskaya sloboda were coopers. At the beginning of the 18th century, the corporate and professional nature of the sloboda was forever lost.
} 
from one of the suburban Moscow estates of the Counts Sheremetev.

The Kadashevskaya and Sadovaya Naberezhnaya slobodas were located on both banks of the Vodootvodny Canal (Figure 1); this is reflected in the toponymy of modern Moscow (Kadashevskaya and Sadovnicheskaya Embankments, Kadashevsky lanes, etc.).

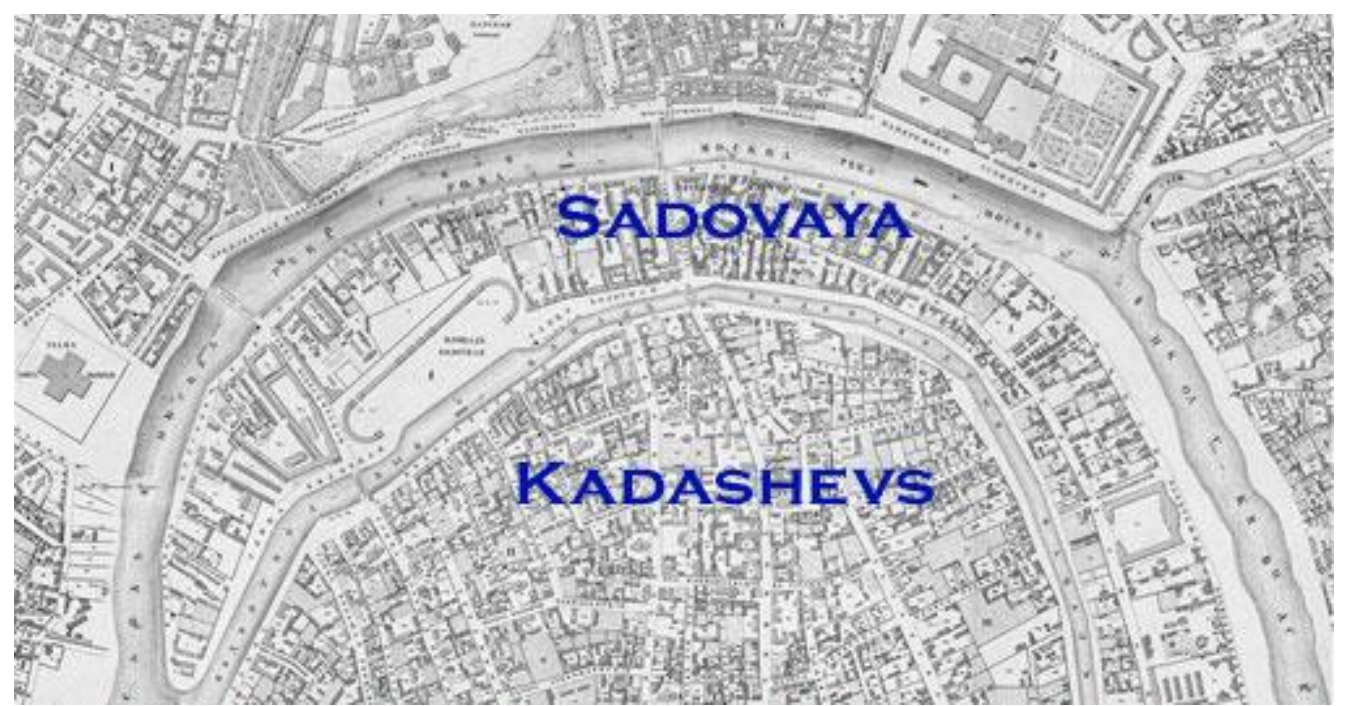

Figure 1. Kadashevskaya and Sadovaya Naberezhnaya slobodas (map of Moscow in 1851)

The Vykhino votchina, consisting of the selo (the village of Veshnyaky) and three derevni ${ }^{4}$ (the villages of Vykhino, Zhulebino and Vyazovka) located close to one another, was situated 10$12 \mathrm{~km}$ from Moscow on Bolshaya Kolomeskaya Road (Figure 2).

Records were used from the revisions ${ }^{5}$ of 1834 and 1850-51 as sources of data on the size and composition of households. The revision household lists of the Vykhino votchina are kept in fund 51, "The Moscow Treasury Chamber", of the Central Historical Archive of Moscow (CHAM). The source of data on merchants' households consists of the revision lists from "Materials for the history of Moscow merchants", a multi-volume work published in 1883-1889 on the proposal of the elected representative of the Moscow merchant class, N.A. Naydenov, seconded at a meeting of representatives on April 8, 1883.

\footnotetext{
${ }^{4}$ Both the selo and the derevnya were populated rural areas, but until 1917 there was a distinct difference: the selo always had a church, that is, it was the centre of a parish uniting several nearby derevnyas.

${ }^{5}$ Poll tax registers introduced by Peter the Great after the basis of taxation in Russia had changed from households to individuals.
} 


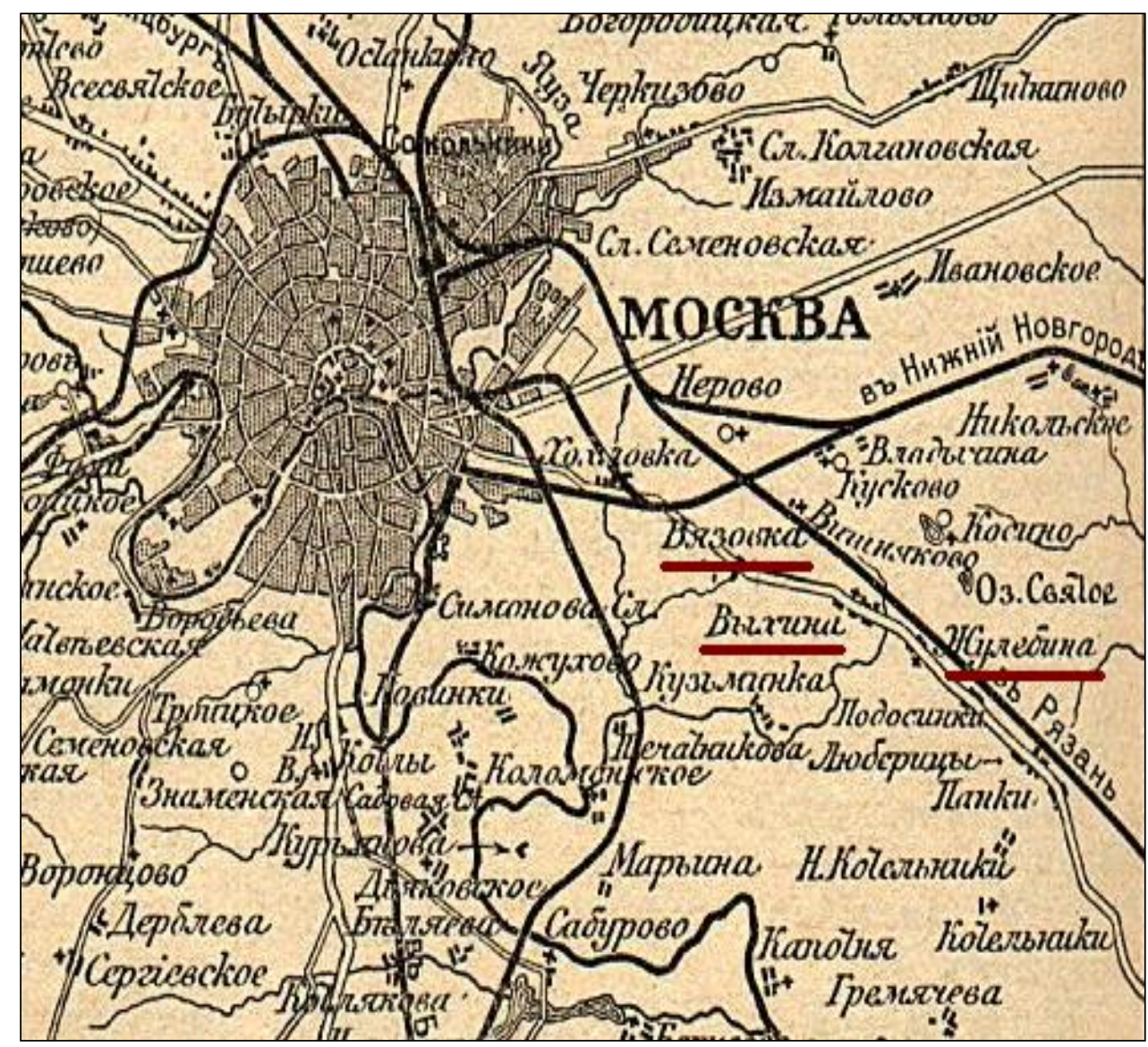

Figure 2. Map of the Moscow region (second half of the 19th century)

Revision lists are a unique source of demographic information containing information about the size and structure of households, kinship ties within the household, the sex and age structure of the population, an age breakdown of deaths, etc. ${ }^{6}$ According to records of the 9th revision, for our sample both social classes being studied had a sex and age structure typical of historical populations: in both groups, a third were children under the age of 15 and the average age was 26 (Figure 3).

\footnotetext{
${ }^{6}$ For more about the revisions as a source of demographic information, see: [Troitskaia 1995].
} 


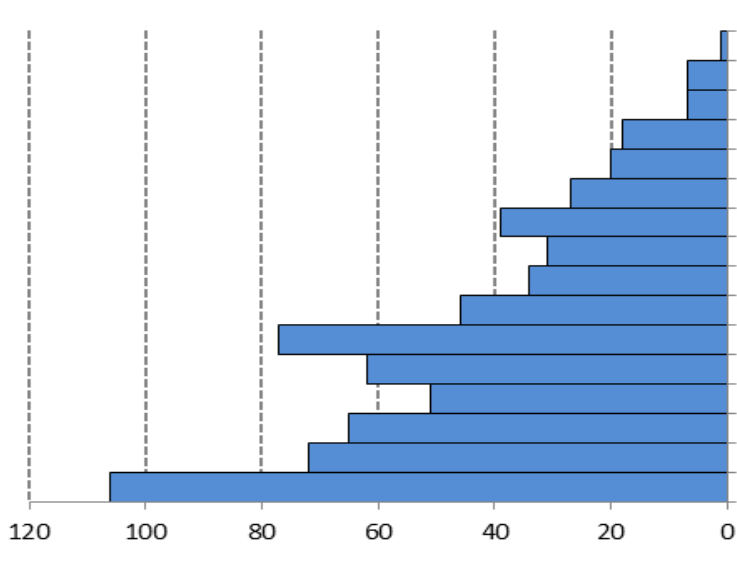

Peasant population, men

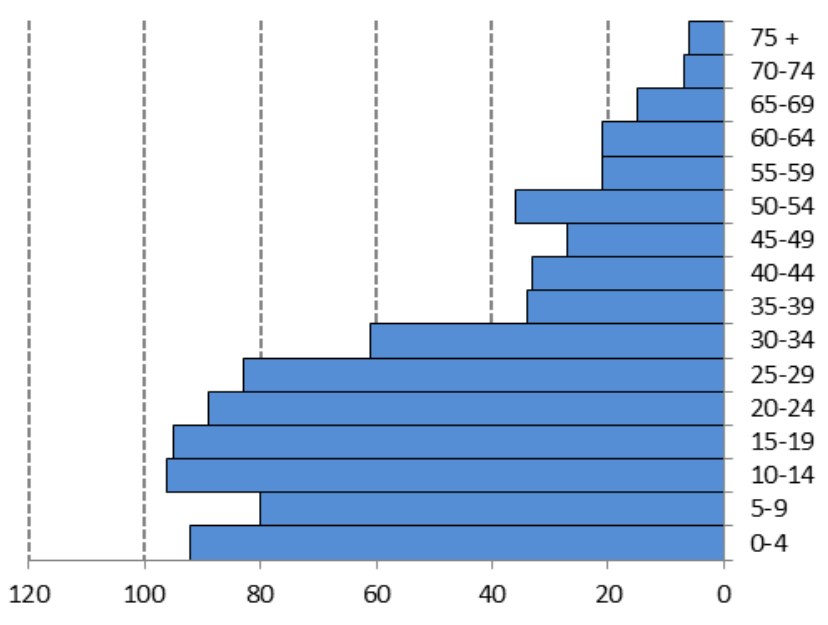

Merchant population, men

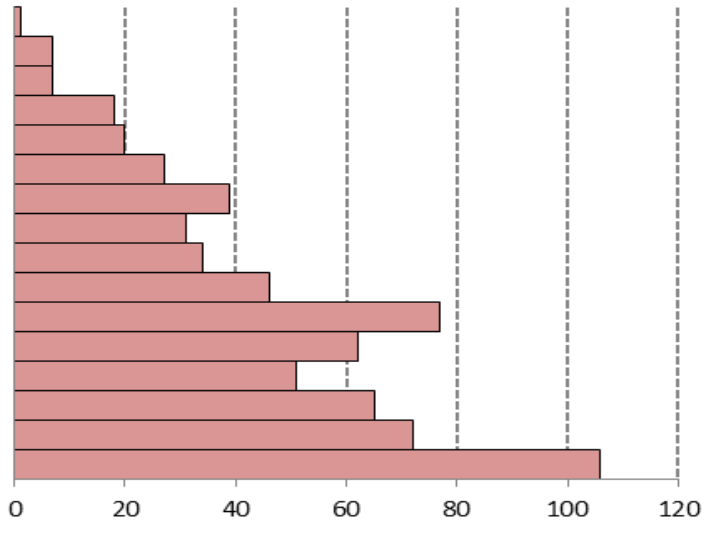

Peasant population, women

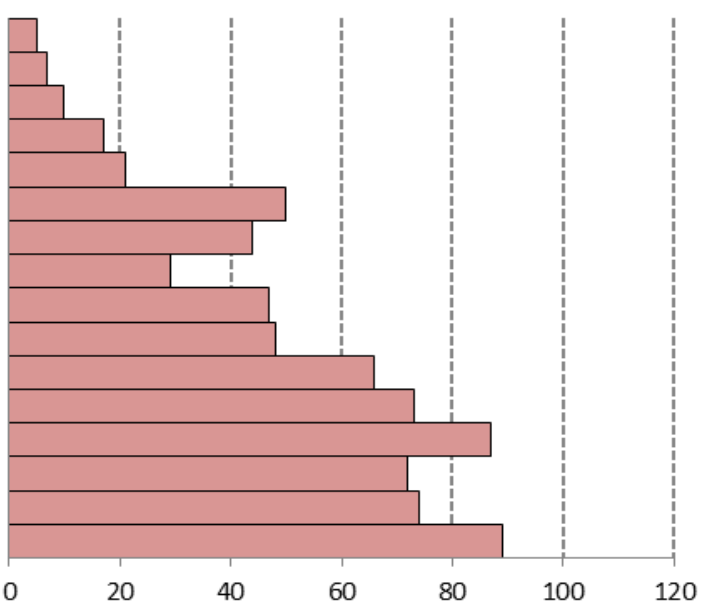

Merchant population, women

Figure 3. Age and sex pyramids of the studied population according to the 9th revision $(1850)$

\section{STRUCTURES OF HOUSEHOLDS: SOCIAL CLASS DISTINCTIONS}

To assess household structures, we used the classification of P. Laslett, although it is often criticised, including in the case of its application to Russian data. However, unsatisfied with the alternative classifications proposed by Soviet or Russian historians, and in order to be able to compare our results with the results of similar studies, we use the above classification. Laslett proposed it in the early 1970s, a time when family history studies, which began in the late 1950s in Western Europe, required generalisation and a basis for comparison of results obtained in different countries.

According to this classification, there are five types of households, ranging from simple ones consisting of a single person to multiple, multigenerational ones involving several couples with or without children. Within each type there are several subtypes, depending on the kinship relations between the members of the household and the head of the household [Laslett 1979]. 
Table 1. Structures of merchant and peasant households according to the 8th revision (1834)

\begin{tabular}{|c|c|c|c|c|}
\hline \multirow{2}{*}{$\begin{array}{l}\text { Category of household according } \\
\text { to the classification of P. Laslett }\end{array}$} & \multicolumn{2}{|c|}{$\begin{array}{l}\text { Merchant Households, } \\
\text { Moscow }\end{array}$} & \multicolumn{2}{|c|}{$\begin{array}{c}\text { Peasant Households, } \\
\text { Vykhino }\end{array}$} \\
\hline & share, $\%$ & average size & share, $\%$ & average size \\
\hline Solitaries & 12.0 & & 6.9 & \\
\hline No family & 2.4 & \#) & 1.7 & \#) \\
\hline Simple family households & 58.1 & $5.07( \pm 2.40)$ & 14.7 & $4.59( \pm 1.80)$ \\
\hline Extended family households & 3.3 & $4.64( \pm 1.12)$ & 12.1 & $6.14( \pm 1.56)$ \\
\hline Multiple family households & 24.3 & $9.70( \pm 4.15)$ & 64.7 & $15.87( \pm 9.71)$ \\
\hline Number of households / & & & & \\
\hline $\begin{array}{l}\text { Total population / } \\
\text { Average household size (all types) }\end{array}$ & & 334 / 1887 / 5.65 & & 116 / 1367 / 11.78 \\
\hline
\end{tabular}

Note: \#) - estimates for category "No family" are not presented due to the small number of such households.

As can be seen from Table 1, at the time of the 8th revision, the merchant class was dominated by the nuclear (simple family) household: a married couple with or without children or a widow/widower with children. These account for about $60 \%$ of the total number of households, whereas in the Vykhino votchina, the share of such households does not exceed $15 \%$. It is interesting that the average size of the merchant nuclear household is 0.5 persons larger than that of the peasant nuclear household. Hypotheses that could explain this difference (e.g. higher fertility, lower infant mortality, later marriage and a smaller proportion of single-parent families in the merchant population) require additional verification. In the peasant population we see the opposite trend: multiple households account for almost $65 \%$ of the total versus $25 \%$ in the merchant population.

Also worth note is the relatively high proportion of single households (solitaries) in the total number of merchant households (12\% versus $6.9 \%$ for peasants) and the very low proportion of extended households consisting of couples with or without children and other unmarried relatives (3.3\% among merchants versus $12.1 \%$ among peasants). The explanation of this is found in the Russian legislation of that period; we will discuss this below.

In the period between the revisions, quite noticeable changes took place in both of the studied populations (Table 2). We note above all a decline in the proportion of multiple peasant households and, very importantly, a decrease in their average size. In addition, during the same period the proportion of nuclear peasant households doubled, while the share of single households fell more than two-fold.

In the merchant population, there was a significant decrease in the proportion of nuclear households, and almost a doubling in the share of singles. To illustrate the nature of the changes in household structures, we have presented the data from Tables 1 and 2 in graphical form in Figure 4.

Our results show a simplification of the structures of peasant households between the 8th and 9th revisions, primarily a reduction in the proportion of medium-sized and multiple households. Whatever the reason for these changes, they give cause to consider the limitations of using P. Laslett's classification to analyse Russian household types. 
Table 2. The structure of households according to the $9^{\text {th }}$ revision $(1850-1851)$, with an evaluation of the differences with the data of the $8^{\text {th }}$ revision (1834)

\begin{tabular}{|c|c|c|c|c|}
\hline \multirow{2}{*}{$\begin{array}{l}\text { Category of household according } \\
\text { to the classification of P. Laslett }\end{array}$} & \multicolumn{2}{|c|}{$\begin{array}{l}\text { Merchant Households, } \\
\text { Moscow }\end{array}$} & \multicolumn{2}{|c|}{$\begin{array}{c}\text { Peasant Households, } \\
\text { Vykhino }\end{array}$} \\
\hline & share, $\%$ & average size & share, $\%$ & average size \\
\hline Solitaries & $21.7 * * *$ & & $2.9^{*}$ & \\
\hline No family & 2.9 n.s & \#) & 2.4 n.s. & \#) \\
\hline Simple family households & $47.9 * * *$ & $4.78( \pm 2.53)$ & $27.1 * * *$ & $3.93( \pm 1.72)$ \\
\hline Extended family households & 4.5 n.s. & $7.57( \pm 2.59)$ & 15.2 n.s. & $5.19( \pm 1.79)$ \\
\hline Multiple family households & $23.0 \mathrm{n} . \mathrm{s}$ & $8.89( \pm 4.13)$ & $52.4^{*}$ & $8.89( \pm 2.85)$ \\
\hline Number of households / & & & & \\
\hline $\begin{array}{l}\text { Total population / } \\
\text { Average household size (all types) }\end{array}$ & & 309 / 1536 / 4.97 & & $210 / 1386 / 6.60$ \\
\hline
\end{tabular}

Notes: $* * * p \leq 0.01 ; * * p \leq 0.05 ; * p \leq 0.1 ;$ n.s. - the differences are non-significant;

\#) estimates for the "No family" category are not presented due to the small number of such households.

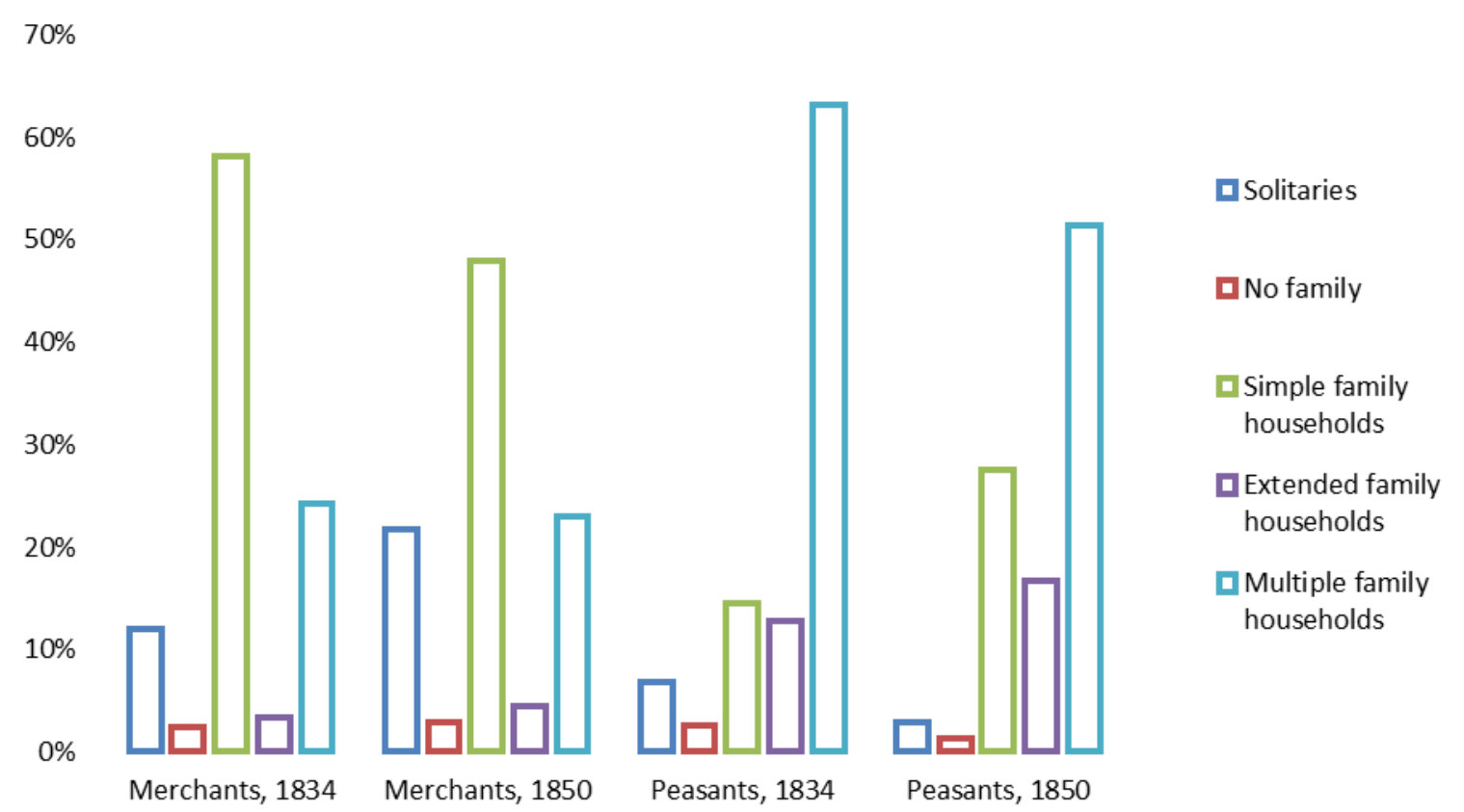

Figure 4. Changes in the structure of merchant and peasant households in the period between the revisions, \%

When discussing multiple households in relation to the historical populations of Europe, in the overwhelming majority of cases we are talking about the "stem family", consisting of a married couple and a married son, either the parents' only son or their potential heir. But in Russia, a multiple family household often includes, in addition to one or more married sons of the household head, indirect relatives (e.g. nephews, cousins, uncles, etc.) with their families. Often the kin relationships between members of the same household were quite distant, and in order to find the common ancestor, thanks to whom they all ended up being recorded in the same household, you had to go back three or four generations. If in such multiple family households there appeared a possibility of division, it generally involved "side branches" splitting off to form their own households. But this process, revolutionary for the Russian multiple family household, is hidden 
by Laslett's classification, as most of the newly formed households were also multiple and therefore remained in the same category. Thus, the proportion of multiple households changed very little, and quantitative changes in structures were expressed only in a significant reduction in the average size of multiple households. If in the classification of Laslett there were a sixth family type (for example, "nested multiple" families, which could include households with, among others, families of indirect relatives of its head), the evolution of family types in Russia would be more obvious (Table 3).

\section{Table 3. Distribution of multiple family households in the Vykhino votchina by family relationship with the household head}

\begin{tabular}{|c|c|c|}
\hline & $8^{\text {th }}$ revision $(1834)$ & $9^{\text {th }}$ revision $(1850)$ \\
\hline $\begin{array}{l}\text { The proportion of multiple family households in the } \\
\text { Vykhino votchina (per Laslett's classification), \% } \\
\text { Of them : }\end{array}$ & 64.7 & 52.4 \\
\hline $\begin{array}{l}\text { Consisting only of direct relatives of the household head } \\
\%^{\#)}\end{array}$ & 42.3 & 47.2 \\
\hline Including indirect relatives, $\%$ & 22.4 & 5.2 \\
\hline $\begin{array}{l}\text { Average size of households consisting only of direct } \\
\text { relatives }\end{array}$ & $12.53( \pm 7.46)$ & $8.85( \pm 2.94)$ \\
\hline Average household size, including indirect relatives & $22.60( \pm 10.41)$ & $9.27( \pm 2.33)$ \\
\hline
\end{tabular}

Note: \#) - This category includes, in addition to "stem" households, so-called "frérèches" consisting of several families of married brothers.

\section{DISCUSSION}

The differences in the structures of merchant and peasant households in the middle of the 19th century can hardly be explained by random variations; the two classes had become too different by that time.

To better understand the factors shaping households in both classes and their representation in the sources, it is necessary above all to recall the purpose of introducing the revision at the beginning of the 18th century. It was meant to record the taxable classes - those inhabitants of the Russian Empire obliged to pay the poll tax - as well as to provide a basis for regular recruiting for military service; in other words, it was meant for calling up a certain percentage, determined by law for each recruitment separately, depending on the domestic and international situation, of the male tax-paying population. Over time, the revisions moved closer to the classical censuses, as they included more and more exempt classes, including that of the merchants, "just for the record".

The duties of peasants and merchants in relation to these basic public service obligations (the poll tax and conscription) were significantly different, a fact which could affect, among other things, the formation of households in each of the classes.

Among the peasant population, responsibility for performing these duties was collective, communal; thus, a large family with a large number of able-bodied men and women, and therefore with a significant land allotment, was a kind of guarantee of their fulfillment. The merchants, on the other hand, bore a personal or family responsibility for payment of the tax, the amount of which did not depend on the household's size and structure, but on the capital declared by its head. As 
for military duty, the merchants were exempt, at first partially, then completely. Thus, there was no particular need to unite several merchant families into one multiple household. Moreover, such unifications had to be carried out according to special rules established by law.

\section{Principles of taxation}

The poll tax was introduced by Peter I in 1718, at the same time as the revision, mainly to maintain the regular Russian army created in that period [Polnoye sobraniye...1830: V. 5:3245]. The average size of the tax was to be calculated by dividing the costs of maintaining the army by the number of taxable persons available, as determined by the revision. The calculated tax replaced all monetary and natural/labour duties formerly imposed on the population.

At the beginning of the introduction of the new tax system, in the merchant class a tax of 40 altyns was levied on each person registered by the revision; in 1775, the poll tax for them was replaced by a so-called "guild tax":

"To divide, as now, merchants possessing a capital of 500 roubles or more into three guilds, and to take from them each one percent per year of their truthfully declared capital, and the poll tax not to take" [Polnoye sobraniye... 1830: V.21: 14327].

The sizes of the guild tax grew constantly. For example, after the reform of 1824 it reached $3-5 \%$ of the stated capital, depending on the guild [Polnoye sobraniye...1830: V.39:30115]; afterwards, right up to 1863 , it remained practically unchanged. But in any case, the head of household (the owner of the merchant's capital) was personally responsible for the payment of the fee, which had nothing to do with the size and structure of the household. In the peasant population, including in the Vykhino votchina, the system of collection and payment of taxes was fundamentally different. On the one hand, the existence of a large household, and therefore of a large number of registered males, increased the formal amount of the poll tax which the household had to pay. But in the peasant community there existed a principle of redistribution of taxes, according to which the total amount designated for payment was divided up among households in accordance with their economic possibilities. The "internal", communal unit of taxation was the tyaglo; more often than not, this was a married couple, as well as single men of working age, capable of paying a partial tyaglo. In any case, each tyaglo was entitled to a plot of land or a part thereof, making it possible to fulfill financial obligations to the state and the landowner. Thus, a greater number of tyaglos in a household meant, on the one hand, a greater tax burden, but on the other hand, more economic prosperity due to the concentration of a significant amount of land held by the household. Therefore, a large and multiple peasant household was in the interests of the landowner, the community and the head of the household, since it served as a kind of guarantee of the fulfillment of their financial obligations to the state.

\section{Obligation to military service}

The peasant population was the main provider of recruits in the Russian army. Regular, almost annual recruitment meant that, in the Vykhino votchina, 2-4\% of the male population of prime working age - 20-35 years - each year left their families, never to return or to return disabled. It was only after the Crimean War that the term of military service became more or less "humane", amounting to 15 years, during a part of which a soldier was in the reserve. By the time of the 
introduction of universal conscription in 1874, the lengths of stay in the active army and in the reserve had become virtually identical -7 and 8 years, respectively. In the peasant population, the system of choosing a family for providing recruits was multiple. There was a recruiting order, which depended largely on the number of adult males in the household - that is, ultimately, on its size and structure - and the just execution of the conscription requirement was seen to by the whole peasant community. The main rule guiding the community was this: conscription was not to weaken the economic opportunities of the household, so that the first recruits were selected from families in which there were three or more men of working age (15-65 years). When all such families had taken their recruiting turn, the next recruits were taken from families with two male workers. Therefore, to ensure the supply of recruits and facilitate their choice, both the peasants' master and the community had an interest in maintaining relatively large and multiple households. Difficulties in selecting recruits were one of the main reasons for prohibiting the breaking up of peasant households:

"Many cases have shown that large peasant families will use all possible means to divide up their families for the sole purpose of getting on the list of small families and single persons, and thus to avoid army recruitment, as well as to be freed from other public duties" [Rossiyskiy gosudarstvennyy...U.321: 39-39].

Documents from the Vykhino votchina contain extensive correspondence with the Board of Housing over the dividing up of peasant families. In 1846, in the village of Vyazovka, the Gusev brothers - Basil, Ilya and Alexei - asked the Moscow Board of Housing for authorisation to divide "by voluntary and amicable agreement, a large but oppressed family, especially when there is a military billeting (when we most definitely have no space in our home)". Despite the approval of this division by a communal assembly of the Vykhino votchina, the Housing Board considered that "The dividing up of the Gusevs is unacceptable, because in theirfamily there are 3 persons in line for recruitment and in their separate houses there will not be two workers each; and for this reason both the request of the Gusevs and the decision of the communal assembly shall not be respected" [Rossiyskiy gosudarstvennyy...U.321: 39-39].

As for the merchant class, it provided a very important privilege: the replacement of military service by payment of a fee for recruits throughout the 18th century. Since the very beginning of conscription, introduced by Peter I, merchants were allowed to "give money for recruits" [Polnoye sobraniye...1830: V.6:3983], though the exact amount was not specified, because it was tied to the size of the annual Zemsky tax. Later, in the Manifesto of the next conscription on September 19, 1776, the amount of payment for a recruit was fixed:

"As Russian merchants, being exempted from the poll tax, pay one percent of their capital, the All-Merciful, discharging them from providing recruits in kind, commands until future regulation that a payment of 360 rubles be exacted from them for each recruit" [Polnoye sobraniye...1830: V.20:14509].

A few years later the amount had risen to 500 rubles on the pretext of "the rise of prices on all things in general" [Polnoye sobraniye...1830: V.21:15721], but in 1807 an imperial manifesto giving the merchants new benefits, distinctions and advantages was announced: 
"As a sign of Our benevolence towards the dignity of the merchant class, the All-Merciful releases from payment of the conscription tax all three guilds in perpetuity" [Polnoye sobraniye...1830: V.29 22418].

Thus, if the merchant families were sometimes large and multiple, the reason for that was not the obligation to provide recruits.

\section{External control of household structures}

Formation of household structures among the merchants was indirectly regulated by law, while the serfs were in this respect in complete subjection to their master.

As noted above, for the master of peasants a large and multiple household with a sufficient number of workers was a kind of guarantee of the performance of their duties. The opinion of an owner of the Vykhino votchina regarding the dividing up of families, although it would evolve over time, in principle supported the existence of large households. The instructions to the managers of the Sheremetev votchinas included several points devoted to such divisions, which essentially boiled down to this: division of a large household must not reduce the economic potential of each of the newly formed households and should not violate the recruiting order. But even fulfillment of these criteria did not give an unconditional right to divide up a household; each case had to be considered separately:

"No one shall be allowed to divide without permission from the Board of Housing, which can allow this only when, in the family requiring division, there are no fewer than two adult workers and the recruiting order is properly maintained. Only then can division of belongings and duties into two houses be allowed with the approbation of the Board of Housing, so that in each house two male souls shall remain; otherwise, fragmentation of families shall not be allowed and shall be strictly monitored" [Rossiyskiy gosudarstvennyy...U.321: 39-39 about].

For unauthorised divisions severe penalties were stipulated, not only for those who divided, but also for their neighbours, who could be fined for failure to report them. This can be considered as yet another example of collective responsibility in the peasant community:

"On September 29, 1841, we, the undersigned peasants of the Vykhino votchina of His Excellency Count Dmitri Nikolaevich, assembled in a full village meeting in the votchina Board, heard Moscow Housing Board order N2521m of the 26th of this September confirming the prohibition on dividing into different families without permission, for which the penalty will be 100 roubles. We pledge to watch out for others and, if anyone should perpetrate an unauthorised family division, to inform the Board, otherwise we give it the full right to collect from the neighbours a penalty of 100 roubles at 10 roubles each; and to this we hereby sign" [Rossiyskiy gosudarstvennyy...U.142: 3].

Since the beginning of the 19th century, the formation of merchant households was controlled, albeit indirectly, by law. According to a Senate Decree of February 28, 1809, the heads of merchant families were allowed to register in their capital only close relatives - their wives, sons, unmarried daughters and, under certain conditions, siblings and grandchildren. This law was passed shortly after the complete exemption of the merchant class from conscription. Its purpose 
was to fight abuses, particularly the attempt of young men to avoid military service who, by registering in the households of their merchant relatives, came under the 1807 Act mentioned above.

The formation of households was affected by other factors (e.g. the relation to land, inheritance principles, particularities of marital behaviour, etc.) which could also determine the differences in the structures of the peasant and merchant households. A detailed study of these factors is beyond the scope of this article.

\section{THE DEMOGRAPHY OF RUSSIAN CLASSES: PROSPECTS FOR FURTHER RESEARCH}

The study of the demographic history of Russian classes seems very promising for several reasons. As mentioned above, the vast majority of historical and demographic research into the times of the Russian Empire focuses on the peasant class. This imposes certain limitations on the analysis of the factors of demographic behaviour of this group due to its homogeneity and negligible territorial and social mobility, especially up to the middle of the 19th century. The merchant class, at least in Moscow, gives many more opportunities for historical and demographic research. First of all, it is a highly mobile population. Passage from one class to another is relatively frequent. Representatives of other classes (petty bourgeoisie, peasants and even nobles) who were able to pay the guild tax and had sufficient capital, joined the merchant class, while merchants unable to pay the guild tax were "demoted" to the class of the petty bourgeoisie. In addition, the class of Moscow merchants was constantly being replenished by new arrivals from other districts of the Moscow province and other provinces.

Another striking feature of merchant households, a feature virtually non-existent in the peasant population, is the role of female household heads. After the death of the head of a peasant household, his role passed, as a rule, to the eldest son or to the eldest man in the family. If a household consisted of a widow with underage children nominally managing the household, she did not have the formal rights of the head; for example, she could not participate in assemblies of the mir. In a merchant household, the role of the head, at least formally, was inherited by a widow, as it was she who acquired the capital and guild status of the deceased husband. Archival documents give us quite a number of examples confirming the important role of widows in managing the business and the home. The same applies to girls who inherited their deceased father's capital [Ulianova 2009: 10-15, 49-54].

A more diverse confessional and ethnic composition also enhances the possibilities for studying the demographics of the merchants. A significant proportion of Old Believers (their share in the Moscow merchants reached 20\%) and a growing number of Catholics and Protestants among Moscow merchants allow us to study the impact of this factor on demographic behaviour, though unfortunately only in the middle of the 19th century. The religious confession of Moscow merchants was indicated only in the last two published revisions, in 1850 and 1858.

A problem with the study of classes other than the peasants is the insufficient number of observations. According to the 1897 census, there were 19,000 merchants, or $2 \%$ of the population 
of Moscow; in the middle of the 19th century, the number of merchants and their families was still 19,000, a figure which barely exceeded $5 \%$. Consequently, certain demographic indicators should be evaluated with caution.

\section{CONCLUSION}

Over the course of the research presented herein, the authors have become convinced once again that the revisions are a source of detailed and high-quality information on the population of the Russian empire in the 18th and 19th centuries, a source which makes it possible to describe the demographic processes of this period in the most modern demographic terms. In particular, study of the revision records of Moscow merchants gives reason to wonder about the social differentiation of the Hajnal model: the class distinctions in household structures observed in Russia in the 19th century are too significant to be explained by only geographical factors or random deviations.

What does this differentiation mean? Does it imply the spread of a new type of demographic behaviour which began with the more developed and affluent classes? Does it point to local features that disappear as the distance from the center increases? What happens in other classes, for example, among the "petty bourgeois" who, on the one hand, are personally free and, like merchants, live in cities, and yet, on the other hand, must perform all obligations to the state just like the peasants? Will their household structure present a kind of intermediate version? Answers to all these questions need to be found, and the authors hope to provide them in future research.

\section{REFERENCES}

Blum A., I. Troitskaya, A. Avdeev (2000). Family, marriage and social control in Russia - three villages in the Moscow region / M. Neven, C. Capron, eds. Family structures, demography and population. A Comparison of societies in Asia and Europe. Liège: Laboratoire de Démographie de l'Université de Liège: 85-110.

Coale A.J. (1969). The decline of fertility in Europe from the French Revolution to World War II / S.J. Behrman, L. Corsa, eds. Fertility and family planning: a world view. Ann Arbor: University of Michigan Press: 3-24.

Coale A.J., B. Anderson, E. Harm (1979). Human Fertility in Russia since the 19th Century. Princeton: Princeton University Press.

Coale A.J., S.C. Watkins, eds. (1986). The decline of fertility in Europe. Princeton: Princeton University Press.

Hajnal J. (1965). European marriage pattern in historical perspective / D.V. Glass, ed. Population in history: essays in historical demography. Aldine Publishing Company: 101-143.

Kaiser D.H. (1992). History urban household composition in early modern Russia // The Journal of interdisciplinary history. 23(1): 39.

Kaser K. (2001). Serfdom in Eastern Europe / D.I. Kertzer, M. Barbagli, eds. The history of the European family. 1. New Haven: Yale University Press: 25-62. 
Knodel J.E. (1974). The decline of fertility in Germany, 1871-1939. Princeton: Princeton University Press.

Laslett P. (1972). Introduction: the history of the family / P. Laslett, R. Wall, eds. Household and family in past time. Cambridge University Press: 3-89.

Laslett P. (1979). Sem'ya i domokhozyaystvo: istoricheskiy podkhod [Family and household: a historical approach] / Brachnost',rozhdayemost', sem'ya za tri veka [Nuptiality, fertility, family over three centuries]. Moskva: Statistika: 132-157.

Lesthaeghe R.J. (1977). The decline of Belgian fertility, 1800-1970. Princeton University Press.

Livi Bacci M. (1971). A century of Portuguese fertility. Princeton University Press.

Livi Bacci M. (1977). A history of Italian fertility during the last two centuries. Princeton University Press.

Mitterauer M. (2003). European kinship systems and household structures: medieval origins / P. Heady, H. Grandits, eds. Distinct inheritances. Property, family and community in a changing Europe Munster. Lit .: 35-52.

Polnoye sobraniye zakonov Rossiyskoy imperii [Complete collection of Laws of the Russian Empire] (1830). Sobraniye pervoye. V 40 tomakh [Collection one. In 40 volumes]. St. Petersburg: Tipografiya II Otdeleniya sobstvennoy Yego imperatorskogo Velichestva Kantselyarii [Typography of the second division of Imperial Office] (in the text the volume and number of the law are indicated).

Rossiyskiy gosudarstvennyy istoricheskiy arkhiv, fond 1088 «Sheremetevy, grafy», opis' 15 «Materialy Vykhinskogo votchinnogo pravleniya Moskovskoy gubernii» [Russian National Historical Archive, fund 1088 "Counts Sheremetev", inventory 15 "Materials Vyhinskogo patrimonial board of the Moscow province" (in the text the storage unit and page number are indicated).

Smith R.M. (1990). Monogamy, landed property and demographic regimes in pre-industrial Europe: regional contrasts and temporal stabilities / J. Landers, V. Reynolds, eds. Fertility and Resources. Cambridge University Press.

Szołtysek M. (2007). Central European household and family system, and the "Hajnal-Mitterauer" line: The parish of Bujakow (18th-19th centuries) // History of the family. 12(1): 19-42.

Tilly C. (1986). Review of the book "A.J. Coale, S.C. Watkins, eds. The decline of fertility in Europe"// Population and development review. 12(2): 323-340.

Todd E. (1983). La Troisième planète: Structures familiales et systèmes idéologiques. Paris: Seuil.

Troitskaya I. (1995). Revizii naseleniya Rossii kak istochnik demograficheskoy informatsii (metodologicheskiye problemy) [Revisions of the Russian population as a source of demographic information (methodological issues)]. $\mathrm{PhD}$ thesis. $\mathrm{M}$.

Ulianova G. (2009). Female entrepreneurs in nineteenth-century Russia. London: Pickering \& Chatto.

Van de Walle E. (1974). The female population of France in the nineteenth century. Princeton University Press. 